\title{
METHOD OF NON-DISASSEMBLY DIAGNOSTICS OF AUTOMOTIVE ENGINES BASED ON PULSE FUNCTIONS OF THEIR SYSTEMS
}

\author{
Farit Khaliullin $^{1,2}$, Alexander Matyashin ${ }^{2}$, Aleksey Martyshev ${ }^{3}$, Nikolay Davidov ${ }^{3}$ \\ ${ }^{1}$ Kazan National Research Technical University named after A. N. Tupolev, Russia; \\ ${ }^{2}$ Kazan State Agrarian University, Russia; ${ }^{3}$ Izhevsk State Agricultural Academy, Russia \\ khaliullin_kai_adis@mail.ru, alex100883@yandex.ru, samosadkinaea@vostok.ru
}

\begin{abstract}
The necessity to determine the technical condition of automotive internal combustion engines arises when their power, economic and environmental indicators deteriorate, as well as before performing the next major repair. Currently, disassembly and non-disassembly methods are used for this purpose. Disassembly methods, although they are the most reliable, are more labor-intensive and require the removal of the engine from the car, the availability of space and equipment for its disassembly. And non-disassembly methods have a low labor intensity, they practically do not require removal of the engine, while providing different reliability of the diagnosis depending on the method used. A method of non-disassembly diagnostics of automotive engines based on the pulse functions of their systems is proposed. As diagnostic parameters here are offered the pulse function of changes in the fuel and air supply of the engine at known values of compression in the cylinders. At the same time, the experience of operating automotive engines shows that the pulse function is a function of the current technical condition of the engine. By using the generalized Bayes formula for determining conditional probabilities, it is possible to determine the probability of failure of engine systems and the current technical condition. The undoubted advantage of the proposed method is its trainability, i.e. with an increase in the statistical data of the diagnosed engines, the reliability of the established diagnosis increases. The offered method will be useful for engineers and technicians involved in the maintenance of internal combustion engines for practical implementation.
\end{abstract}

Keywords: non-disassembly diagnostics, pulse function, diagnostic parameter, adequacy of the diagnosis.

\section{Introduction}

Technical operation of machine-tractor units (MTU) in the conditions of agriculture involves carrying out certain diagnostic actions on their components and aggregates to determine the technical condition of these machines. Special attention is paid to the technical diagnostics of machine engines, since agriculture engines operate under conditions of unsteady load, which leads to accelerated wear.

There are many different ways to diagnose internal combustion engines (ICE) of agricultural mobile machines, designed both for solving technical diagnostics and for solving technical forecasting problems, since in agriculture it is important to have not only accurate data on the current technical condition of the machine, but also on the remaining resource.

The classification of diagnostic methods is shown in Fig. 1. The most traditional disassembly methods for diagnosing the technical condition of engines involve physical impact on the components and assemblies of the engine being diagnosed with the disconnection of some of them from the engine and subsequent direct or indirect measurement of the parameters of interest to the diagnostician. Such methods include, for example, diagnosis of fuel equipment elements on stands or devices. At the same time, it is possible to divide disassembly methods of diagnostic into those that require complete removal of equipment from engines and those that require partial removal of equipment [1]. According to [2], the nodes that are subject to partial disassembly are diagnosed by the method of technical endoscopy, where fiber-optic devices - endoscopes are used.

There are many methods of non-disassembly diagnostics, which are carried out in statistical and operational modes.First of all, it is worth highlighting the methods of vibroacoustic (VA) diagnostics [3], the essence of which is the registration, processing and interpretation of vibration or noise indicators of MTU engines. At the present stage of development of VA-technologies of diagnostics, the following advantages can be distinguished:

- the ability to diagnose breakdowns and identify defects at an early stage;

- the ability to predict the future operation of components or the machine as a whole, as well as planning the scope of maintenance and repair work;

- the efficiency of collecting information about the technical condition of the equipment and the mobility of the VA equipment. 


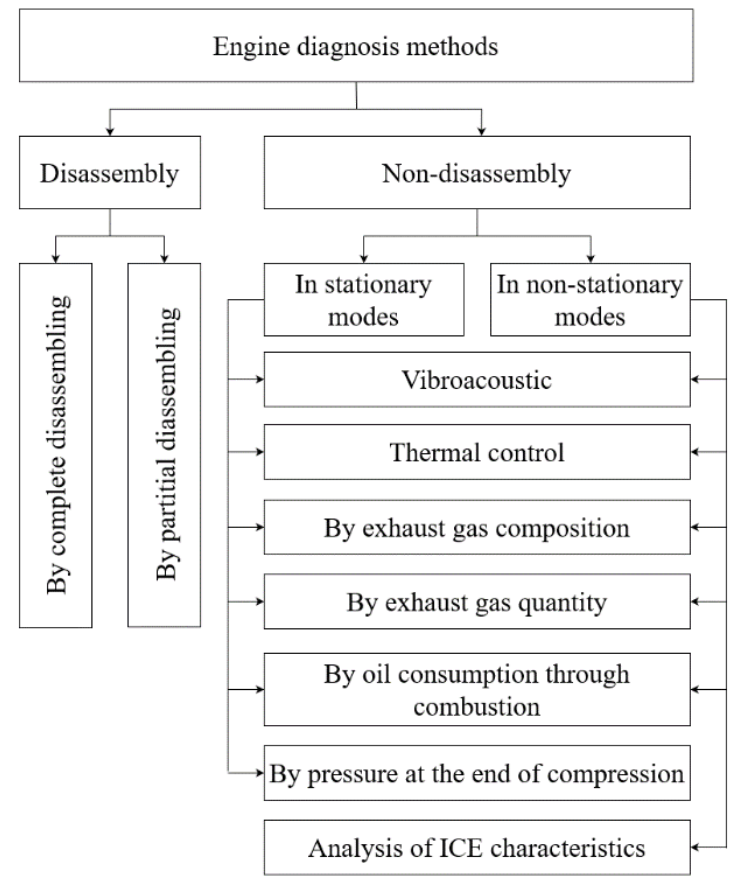

Fig. 1. Methods for diagnosing internal combustion engines

The main problems that complicate the use of vibroacoustic methods of non-disassembly diagnostics include increased requirements for processing the received signal, the limited use of Fourier transforms for non-stationary processes [4]. Vibration also depends on the time of transient response and for some engine models, at the end of the transient response of the acceleration characteristics, there is a spontaneous appearance of additional vibrations for a short time [5; 6].

Methods of thermal control are based on measuring the temperature of the object being diagnosed, as well as its further analysis. During the operation of the engine, the generated thermal energy is transferred to the surface of the object.An analog of thermal control can be considered laser control methods with the application of fluorescent compositions or the use of special endoscopes [7;8].Both thermal and laser control methods are of limited use in the operational diagnostics of internal combustion engines, since the temperature of engine components is a slowly changing parameter.In addition, as a rule, such methods require additional control of other parameters of the ICE.

The method of analysis of the composition and amount of exhaust gases of the engine allows to determine the nature and conditions of the combustion process, and based on the value of the excess air coefficient, to estimate the maximum permissible wear of parts of the cylinder-piston group (CPG). The main disadvantages of this method include the impossibility of operational control of the engine condition and weak prognostic capabilities for determining the residual life of the engine [9]. In addition, the obvious disadvantage of this method is the ability to evaluate only the state of the CPG, but not the overall state of the engine.

To assess the technical condition of the internal combustion engine, a method based on monitoring the current values of the concentrations of wear products is also interesting. During the operation of the ICE, wear products are collected in the engine oil, which come from various parts, which makes it a carrier of information about the technical condition of the engine [10].

To assess the technical condition of the CPG, such an indicator as the oil consumption through combustion is also used, which makes it possible to determine the type of necessary repairs, if there is a correct accounting.However, the oil consumption for the period from the beginning of the engine operation to major repairs increases by 3-5 times, and depends on the operating conditions of the engine, so to assess the technical condition of the CPG for oil consumption through combustion, it is necessary to operate the equipment in the same conditions, which is impossible during agricultural work.

The technical condition of the CPG is also determined by the pressure at the end of compression. The disadvantage is that at extreme wear there may be a slight change in compression due to significant oil 
consumption, sealing the coupling of the CPG [11].It should be noted that the compression value is also affected by the leakage of the valves of the gas distribution mechanism, and not only the wear of the CPG.When assessing the technical condition, the compression value is not reliable, since the pressure at the end of compression depends not only on the state of the CPG, but also on the speed of the crankshaft, and its constancy cannot be achieved when using the starter.

The advanced methods of internal combustion engine diagnostics also include the radio-wave method of condition assessment [13], methods using built-in diagnostic elements [14; 15], and modeling of the diagnostic process using a neuro-fuzzy diagnostic system [16].

It is known that the diagnosis of ICE is carried out both in stationary and non-stationary modes. A more convenient and operational method is the non-stationary mode of studying the ICE.

The fundamentally dynamic method can be implemented in two modes of diagnostic tests:

- In an unsteady (transient) acceleration with full supply or run-out with the fuel supply cut off in all or part of the cylinders;

- In the steady state, assuming the operation of the engine with the loading of the brake stand, or when performing transport work.

In technical diagnostics, due to the ease of implementation, the Fourier harmonic series analysis method is used, the essence of which is to identify the main harmonics with subsequent detection of the amplitude and frequency spectra, which allows to extract the spectrum of the signal under study and then identify the fault $[17 ; 18]$. However, the well-known Fourier analysis has a number of disadvantages, among which the main ones are:

1. Insufficient information content and almost complete lack of analysis capabilities for the time of occurrence and the shape of the amplitudes, weak capabilities in cleaning up noise.

2. Harmonic Fourier constructions do not have the ability to reliably reflect the shape of signals with a large steepness of harmonics, since this requires cumbersome construction of digital series.

Due to the fact that the above method has a sufficient number of limitations, the method of wavelet analysis of ICE characteristics is increasingly used, which is an alternative and eliminates the disadvantages of the Fourier series analysis method, and provides a more flexible signal processing technique.This transformation method is detailed and time-weighted or space-argument-based by means of signal representation.A distinctive feature of the Fourier transform is that the wavelet transform of one-dimensional signals provides their two-dimensional representation, while the frequency and coordinate are considered as independent variables, which allows simultaneous analysis of signals in two dimensions [19].However, the method of wavelet analysis has not been widely used to date, due to the software and hardware limitations of using this method.

\section{Status of the issue}

The main task of technical diagnostics is to recognize the state of a technical system in conditions of limited information. But based on the available information, it is not always possible to draw a clear conclusion and it is necessary to use statistical methods.

The method of sequential analysis (Wald method) is used for differential diagnostics, i.e. recognition of two states, serviceable and faulty. Surveys are conducted as necessary to make a decision with a certain degree of risk, their number is not set in advance.In this method, the probability ratios of features are compiled sequentially, rather than immediately, so a smaller number of surveys is usually required [20].

Due to its simplicity and efficiency, the most common method is based on the generalized Bayes formula. This method has its drawbacks, such as a large amount of preliminary information and rare diagnoses. But if the amount of statistical information allows to use this method, it is advisable to use it as one of the most reliable and effective. This method is used in the diagnosis of the technical condition of tractors, cars, railway transport, and aircrafts [21].

It is also worth noting the promise and convenience of using the Bayes algorithm for predicting the failure of the internal combustion engine in that this formula can be more accurately recalculated probability, using both previously known statistical information and data from new tests. 


\section{Offered solution}

For the diagnosis of ICE malfunctions, a method based on the application of the Bayes algorithm is proposed, with the selected diagnostic parameters, the basics of which are proposed in the works [2225]. In them, the internal combustion engine is considered as a dynamic system with stationary and deterministic characteristics, which allows to use identifying methods of dynamic systems.

The most common and well-developed from a methodological point of view is the identification of dynamic systems using impulse functions [26]. According to this method, the analytical expression of the impulse response is determined by the reaction of the object to the impulse change of the control signal at the input.

The long-term and significant impact that has to be applied to obtain the acceleration characteristics of the ICE causes long-term changes in its operating mode and therefore is not always permissible on existing facilities. Reducing the magnitude of the effects when removing the acceleration characteristics is advisable only to certain limits, because otherwise the applied effect will be commensurate with the random disturbances that occur during the experiment. If a long-term violation of the regime is impossible under production conditions, then it is usually not the amount of exposure that is reduced, but its duration. In this case, the dynamic properties of the object can be determined not by the acceleration, but by the impulse response.

The pulse characteristic is a curve of the change in the controlled parameter as a result of a temporary pulse action, that is, such a pulse when the applied stepwise action is completely removed after a certain period of time $\Delta t$. The impulse action can be considered as the action of two equal and opposite in the direction step actions, of which the second is applied later than the first on $\Delta t$.

The acceleration characteristic can be constructed from the impulse one, taking advantage of the fact that in the case of linearity of the static characteristics of the control object, the deviation of the controlled parameter obtained as a result of several actions is equal at any given time to the algebraic sum of the deviations of the controlled value due to each of the actions separately. This is a consequence of the additivity (or superposition) of the transition functions. On this basis, the impulse response can be represented as an algebraic sum of two identical, but opposite in the direction of the deviation curves of the parameter $y_{1}$ and $-y_{2}$, of which the second is delayed in comparison with the first by $\Delta t_{\lambda}$, that is, by the duration of the pulse action.

The second stage of the development of the algorithm for non-disassembling engine diagnostics is the selection of diagnostic criteria and the determination of the ranges of their changes in accordance with the technical condition of the object of study (Fig. 2).

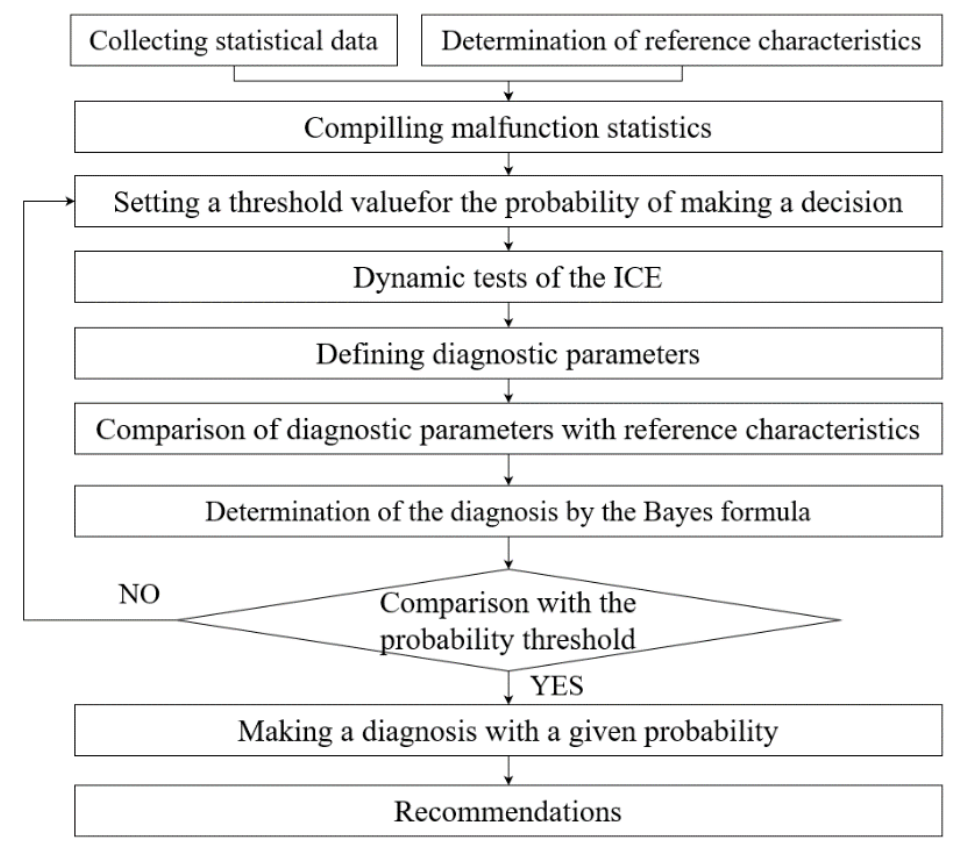

Fig. 2. Algorithm of non-disassembly diagnostics of ICE 
These data are determined as a result of tests on the stand [26] for each combination of state parameters according to the plan and algorithm of the experiment. The correct choice of diagnostic parameters (signs) is quite a crucial moment, since it affects not only the reliability of the diagnosis, the number of experiments to obtain it, but also reduces the probability of errors of the first and second kind. Considering an internal combustion engine as a dynamic object with stationary characteristics, it is allowed to use methods for identifying such objects.

They reflect the dynamic characteristics of the system and depend on its technical condition. As a diagnostic feature, let us choose changes in the engine performance, when the position of the regulator adjustment lever is changed impulsively - pulse functions:

- pulse function of rotation frequency $T_{n}\left(k_{1 i}\right)$;

- pulse function of changing the fuel supply $T_{g c}\left(k_{2 i}\right)$ (see Fig. 3);

- pulse function of air consumption $T_{G b}\left(k_{3 i}\right)$.

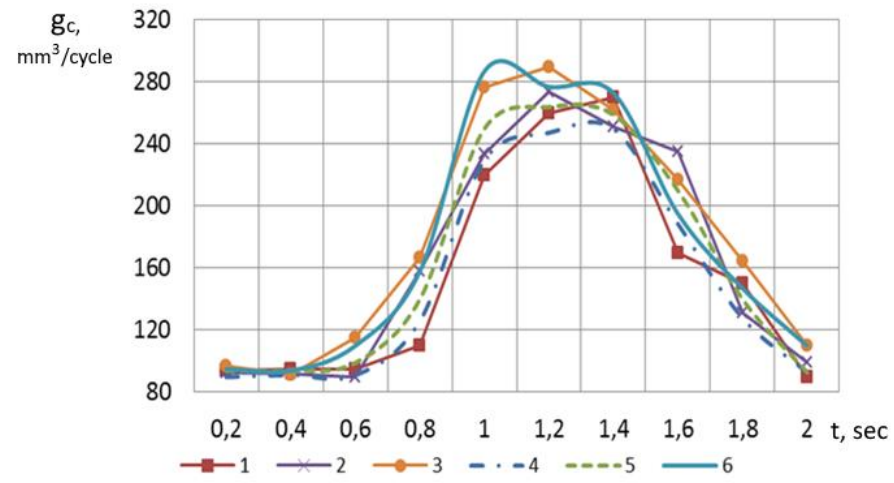

Fig. 3. Pulse functions of the cyclic fuel supply depending on the fuel injection pressure of D-243 engine: 1,4 - at a fuel injection pressure of $18,5 \mathrm{MPa}$;

$2,5-$ at a fuel injection pressure of $16.5 \mathrm{MPa}, 3,6-$ at a fuel injection pressure of $15.5 \mathrm{MPa}$

When determining a diagnosis based on the technical condition of an internal combustion engine using the Bayes method, it is considered necessary to draw up a diagnostic table (matrix), the elements of which are formed on the basis of previously collected statistical material. The diagnostic table contains conditional probabilities of bit depths of a set of signs for various technical conditions of the engine (diagnoses).And the dimension of the table is determined by the number of selected probable manifestations of signs of failures and faulty states.

The diagnostic table includes only the a priori probabilities of the selected diagnoses.

To obtain diagnostic results with a high probability of reliability, when filling in this matrix, it is necessary to keep a continuous record of the technical condition of the engine during each regular maintenance with the state of its systems and mechanisms.According to the results of practical diagnostic studies, a satisfactory convergence of the results appears when the sample size is greater than 200.One of the issues that cause difficulties when filling out the Bayes diagnostic table is the fact that, according to the regulatory and technical documentation, not all the necessary information on the technical condition of the engine components is recorded during these works.

Let us consider an example of drawing up a diagnostic table using the Bayes algorithm for the D243 engine.

The experience of operating internal combustion engines and the content of work in accordance with the regulatory and technical documents for their maintenance show that its current state is primarily determined by the state of the air supply systems (SPV) and fuel (SPT), as well as the cylinder-piston group (CPG) [22].

As a diagnosis, let us choose four main engine conditions:

- malfunctions in the air supply system (SPV);

- malfunctions in the fuel supply system (SPT);

- malfunctions of the cylinder-piston group (CPG); 
- working condition of the engine.

Each feature has three status levels: good, satisfactory, and unsatisfactory, corresponding to a system malfunction:

- intensity of the change is good $k_{j l}$;

- intensity of the change is satisfactory $k_{j 2}$;

- intensity of the change is poor $k_{j 3}$.

To determine the range of changes in indicators from a good to a bad value, information on the correspondence of these data for engines with zero and maximum operating time is required [24].These characteristics are determined according to regulatory and technical documents or they can be obtained in bench tests of engines with different technical conditions, and they are used to determine the boundary conditions during diagnostics: as a result, there are three ranges for each diagnostic parameter: good $\left(k_{i 1}\right)$, satisfactory $\left(k_{i 2}\right)$ and poor $\left(k_{i 3}\right)$ (Table 1$)$.

The Bayes diagnostic table for engine failures and malfunctions with the selected diagnostic parameters is shown in Table 1 below.

Table 1

Bayes diagnostic table

\begin{tabular}{|c|c|c|c|c|c|c|}
\hline \multirow[t]{3}{*}{ Engine state $D_{i}$} & \multicolumn{5}{|c|}{ Signs $_{j}$} & \multirow[t]{3}{*}{$P\left(D_{i}\right)$} \\
\hline & \multicolumn{2}{|c|}{$\begin{array}{c}\text { Rotation frequency } \\
k_{1}\end{array}$} & \multicolumn{2}{|c|}{$\begin{array}{l}\text { Fuel consumption } \\
\qquad k_{2}\end{array}$} & $\begin{array}{c}\text { Air consumption } \\
k_{3}\end{array}$ & \\
\hline & $k_{11}$ & $k_{13}$ & $k_{21}$ & \begin{tabular}{|l|l|}
$k_{22}$ & $k_{23}$ \\
\end{tabular} & \begin{tabular}{l|l|l}
$k_{31}$ & $k_{32}$ & $k_{33}$ \\
\end{tabular} & \\
\hline $\begin{array}{l}\text { Malfunctions } \\
\text { ofSPV } D_{1}\end{array}$ & \multicolumn{2}{|c|}{$P\left(k_{1 i} / D_{1}\right)$} & \multicolumn{2}{|c|}{$P\left(k_{2 i} / D_{1}\right)$} & $P\left(k_{3 i} / D_{1}\right)$ & $P\left(D_{1}\right)$ \\
\hline $\begin{array}{l}\text { Malfunctions } \\
\text { ofSPT } D_{2}\end{array}$ & \multicolumn{2}{|c|}{$P\left(k_{1 i} / D_{2}\right)$} & \multicolumn{2}{|c|}{$P\left(k_{2 i} / D_{2}\right)$} & $P\left(k_{3 i} / D_{2}\right)$ & $P\left(D_{2}\right)$ \\
\hline $\begin{array}{l}\text { Malfunctions of } \\
\mathrm{CPG} D_{3}\end{array}$ & \multicolumn{2}{|c|}{$P\left(k_{1 i} / D_{3}\right)$} & \multicolumn{2}{|c|}{$P\left(k_{2 i} / D_{3}\right)$} & $P\left(k_{3 i} / D_{3}\right)$ & $P\left(D_{3}\right)$ \\
\hline Working condition $D_{4}$ & \multicolumn{2}{|c|}{$P\left(k_{1 i} / D_{4}\right)$} & \multicolumn{2}{|c|}{$P\left(k_{2 i} / D_{4}\right)$} & $P\left(k_{3 i} / D_{4}\right)$ & $P\left(D_{4}\right)$ \\
\hline
\end{tabular}

where $P\left(D_{i}\right)$ - priori probability of hypothesis $D_{i}$;

$P\left(k_{j} / D_{i}\right)$ - probability of the hypothesis $k_{j}$ at the occurrence of the event $D_{i}$ (a posteriori probability).

These values are related by the Bayes formula:

$$
P\left(\frac{D_{i}}{k_{j}}\right)=P\left(D_{i}\right) \frac{P\left(\frac{k_{j}}{D_{i}}\right)}{P\left(k_{j}\right)},
$$

where $P\left(k_{j}\right)$-total probability of occurrence of the event $k_{j}$;

$P\left(D_{i} / k_{j}\right)$ - probability of occurrence of the event $D_{i}$, when the hypothesis $k_{j}$ is true.

\section{Conclusions}

A method for diagnosing internal combustion engines, based on the impulse functions of its fuel and air supply systems, based on the Bayes algorithm is proposed. At the same time, the technological process of engine diagnostics is easily automated and allows to reduce the so-called "human factor". Also of particular value is the possibility of improving the adequacy of diagnostic results as the database of statistical data on the engines under consideration accumulates.

The economic effect of the introduction of the developed method of engine diagnostics is achieved by reducing the complexity of the process [22]. The proposed method increases productivity compared to existing methods by $30-40 \%$, and also reduces labor intensity by $25-35 \%$. Based on the developed method, it is planned to continue research on the definition and refinement of diagnostic parameters for modern engines with various types of faults, as well as to expand the field of application of the developed method for assessing the residual life of modern engines. 


\section{References}

[1] Крашенинников С.В. Современные подходы к диагностированию дизельных двигателей внутреннего сгорания (Modern approaches to the diagnosis of diesel internal combustion engines)Russian journal of sciences: Вестник Новосибирского государственного педагогического университета, 2013, №12,pp. 59-68 (In Russian).

[2] Кузнецов А.С. Техническое обслуживание и диагностика двигателя внутреннего сгорания: учебное пособие (Internal combustion engine maintenance and diagnostics). Moscow, Academy Publ, 2013, 80 p. (In Russian).

[3] Лютин К.И. Использование нейронно-сетевых моделей при виброакустической диагностики ДВС на примере диагностики кулачкового ГРМ. Диссертация на соискание ученой степени к.т.н. (The use of neural network models for vibroacoustic diagnostics of internal combustion engines on the example of diagnostics of a cam gas distribution mechanism. Ph.D Thesis).Volgograd State Technical University, 2009, 132 p. (In Russian)

[4] Суранов Г.И. Повышение долговечности транспортных двигателей. Монография.(Improving the durability of transport engines. Monography.).Ukhta,UGTU Publ, 2011, 335 p. (In Russian)

[5] Чурилин A.C. Оперативная виброакустическая диагностика автомобилей (Rapid vibroacoustic diagnostics of cars) Russian journal of technical sciences: Техникотехнологические проблемы сервиса.2011,no. 17. pp. 20-22. (In Russian)

[6] Machalik S. Využitíobrazovéanalýzy v tribotechnickédiagnostice (Image Analysis in Tribodiagnostics). Pardubice: University of Pardubice, 2013. 112 p.

[7] Gessenhardt C. et al. Hybrid Endoscopes for Laser-Based Imaging Diagnostics in IC Engines. SAE Tech. Pap. 2009. № 1. P. 11.

[8] Snyder J.A. Development and Application of Tracer-Based Planar Laser-Induced Fluorescence Imaging Diagnostics for HCCI Engines. Stanford University, 2011. 172 p.

[9] Николаев Е.В. Совершенствование технологии диагностирования цилиндропоршневой группы дизельного двигателя по параметрам картерных газов. Диссертация на соискание ученой степени к.т.н.(Improvement of the technology for diagnosing the cylinder-piston group of a diesel engine by the parameters of crankcase gases. Ph.D Thesis). GNU GOSNITI Rosselkhozakademii Publ., 2013. 17 p. (In Russian)

[10] Wani M.F. Development of design methodology for mainatinability of mechanical systems. InidainInstitue of Technology, 1999. $205 \mathrm{p}$.

[11]Пестриков B.М., Евкарпиев В.Е. Особенности диагностики современных автотранспортных средств (Featuresof diagnostic sofmodern motor vehicles). Russian journal of technical sciences: Технико-технологическиепроблемысервиса.2014, no. 4(30) - pp.15 (In Russian)

[12] Guzzomi F.G., O’Neill P.L., Tavner A.C.R. Investigation of Damper Valve Dynamics Using Parametric Numerical Methods.Proceedings of 16th Australasian Fluid Mechanics Conference,Dec. 2-7, 2007, Crown Plaza, Gold Coast, Australia,pp.1123-1130.

[13] Skripnik, Yu.,Gorkun, V., Shevchenko, K. Radiowave method of internal combustion engines' condition estimation.Proceedings of 16th International Crimean Microwave and Telecommunication Technology, CriMiCo, 2006, p. 861-863, 4023516

[14] Aronson, K.E., Murmansky, B.E., Brodov, Y.M., Sosnovsky, A.Y., Murmanskii, I.B. Determining Prototypes and Signs for Automated Diagnostics of Steam Turbine Equipment. Journal of sciences:Thermal Engineering, 2020, no.67(9), p. 647-654

[15] Murmanskii, I., Aronson, K., Murmansky, B., Novosyolov, V., Brodov, Y. Features of steam turbines diagnostics Proceedings of E3S Web of Conferences, 2020, pp.178, 01059

[16] Galiullin L.; Valiev R. Diagnostics technological process modeling for internal combustion engines.Proceedings of International Conference on Industrial Engineering, Applications and Manufacturing, ICIEAM-2017, 2017

[17] V. S. Avramchuk, V. P. Kazmin, V. A. Faerman and V. T. Le The time-frequency method of signal analysis in internal combustion engine diagnostics. International Conference on Information Technologies in Business and Industry 2016 IOP Conf. Series: Journal of Physics: Conf. Series 803 (2017) 012012 DOI: 10.1088/1742-6596/803/1/012012

[18] Фатьянов М. П. Применение метода кросс-вейвлетов для анализа финансовых рядов [Application of the cross-wavelet method for financial series analysis].Russian journal of sciences: Молодойученый, 2014,no 3,pp.83. (In Russian) 
[19] Шиндор О.А. Методика контроля критических режимов работы высокоэнергетических установок на основе вейвлет-анализа их нестационарных флуктуационных и шумовых сигналов. Диссертация на соискание ученой степени к.т.н. (Method of control of critical operating modes of high-energy installations based on the wavelet analysis of their non-stationary fluctuation and noise signals. Ph.D Thesis.). Kazan, 2015. 164 p. (In Russian)

[20]Кабикенов С.Ж., Интыков Т.С., Кириевский М.М., Шалаев В.В. Основы технической эксплуатации транспортной техники (Fundamentals of technical operation of transport equipment). Karaganda, KarGTU Publ., 2015. 261 p. (In Russian)

[21] Лукасов В.В., Никушкин Н.В. Применение методики поиска неисправностей по теореме гипотез (метод Байеса) в диагностике авиационной техники(Application of the method of troubleshooting according to the hypothesis theorem (Bayes method) in the diagnostics of aviation equipment),Russian journal of sciences: Вестник Сибирского государственного аэрокосмического университета им. академика М.Ф. Решетнева, 2007, no. 4,pp.71-73. (In Russian)

[22] Ахметзянов И.Р. Разработка метода безразборной диагностики двигателя МТА на основе переходных функций его систем с применением алгоритма Байеса. Диссертация на соискание ученой степени к.т.н.[Development of a method for non-disassembling diagnostics of the MTA engine based on the transient functions of its systems using the Bayes algorithm. Ph.D. Thesis]. Kazan, 2017. 171 p. (In Russian)

[23] Khaliullin F.K., Matyashin A.V., Akhmetzyanov R.R., Medvedev V.M., Lushnov M.A. Prospects for using the bayes algorithm for assessing the technical condition of internal combustion engines.Proceedings of 10th International Conference on Mechatronics and Manufacturing (ICMM 2019), January21-23,2019, Bangkok, Thailand, Volume 635(1), 012016

[24] Khaliullin, F., Aladashvili J.K., Nurmiev A.A., Pikmullin G.V., Sinitsky S.A. Determination of statistical data of conditional probabilities of the technical condition of internal combustion engines when compiling the Bayes diagnostic table. Proceedings of 10th International Conference on Mechatronics and Manufacturing (ICMM 2019), January 21-23, 2019, Bangkok, Thailand, Volume 635(1), 012017

[25] Khaliullin F., Akhmetzyanov R., Arslanov F., Korepanov Yu. Method for determining remaining life of engine by dynamic characteristics.Proceedings of 19th International Scientific Conference Engineering for Rural Development, ERD 2020, May 20 - 22, 2020 Jelgava, Latvia, pp. 1096-1101

[26] Дилигенская А.Н. Идентификация объектов управления.[Identification of management objects]. Samara State technical university Publ., 2009.pp.43-50 (In Russian). 